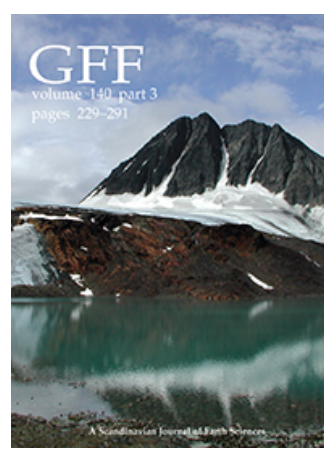

GFF

\title{
Acanthodians from the Silurian-Devonian boundary beds of Novaya Zemlya Archipelago, Russia
}

\author{
Carole J. Burrow, Alexander O. Ivanov \& Victoria B. Ershova
}

To cite this article: Carole J. Burrow, Alexander O. Ivanov \& Victoria B. Ershova (2018)

Acanthodians from the Silurian-Devonian boundary beds of Novaya Zemlya Archipelago, Russia, GFF, 140:3, 241-248, DOI: 10.1080/11035897.2018.1474381

To link to this article: https://doi.org/10.1080/11035897.2018.1474381

曲 Published online: 11 Jun 2018.

Submit your article to this journal $\widetilde{ }$

Џ Article views: 67

View Crossmark data $\complement$ 


\title{
Acanthodians from the Silurian-Devonian boundary beds of Novaya Zemlya Archipelago, Russia
}

\author{
Carole J. Burrow ${ }^{\mathrm{a}}$ (D), Alexander O. Ivanov ${ }^{\mathrm{b}, \mathrm{c}}$ (D) and Victoria B. Ershova ${ }^{\mathrm{b}}$ \\ ${ }^{a}$ Geosciences, Queensland Museum, Brisbane, Australia; 'b Institute of Earth Sciences, Saint Petersburg State University, St. Petersburg, Russia; ${ }^{\circ}$ Kazan \\ Federal University, Kazan, Russia
}

\begin{abstract}
An acanthodian assemblage is reported for the first time from the Silurian-Devonian boundary beds of Novaya Zemlya Archipelago, Russia. The acanthodian scales and rare other vertebrate microremains were in a sample collected from the Reliktovoe Formation of the western coast of Inostantzev Bay, North Island. The assemblage includes Gomphonchus mediocostatus, Gomphonchoporus hoppei taxa previously described from the Pridoli - Lochkovian of Laurussia, and Taimyrolepis composita occurred in the Lochkovian of Siberia. Gomphonchus mediocostatus and Gomphonchoporus hoppei are widely distributed in the Baltica palaeogeographic province, and Taimyrolepis is known from the Siberia province, indicating connection between those provinces.
\end{abstract}

ARTICLE HISTORY

Received 9 March 2018

Accepted 5 May 2018

\section{KEYWORDS}

Acanthodii; Pridoli Lochkovian; Novaya Zemlya; Russia; Gomphonchus mediocostatus; Gomphonchoporus hoppei; Taimyrolepis composita

\section{Introduction}

Data on the vertebrates from the Silurian - Lower Devonian of Novaya Zemlya Archipelago are extremely rare. The oldest known collection of Early Devonian fossil fish from Novaya Zemlya was made in 1921 by O. Holtedahl (Nakrem 2007). Obruchev (1973) mentioned the occurrence of sarcopterygian Porolepis sp. in the Lower Devonian of Morzhovaya Bay, south-western Novaya Zemlya. Mark-Kurik \& Novitskaya (1977) reported vertebrates from the Lochkovian Veselaya Gora Formation of Schmidt Peninsula on North Island, Novaya Zemlya. The assemblage includes two heterostracans resembling Doryaspis and Gigantaspis, osteostracan Cephalaspis sp., placoderm Arctolepidida n. gen.?, acanthodians and sarcopterygian Porolepis? sp. (Mark-Kurik \& Novitskaya 1977; Pernègre \& Blieck 2016). Two types of acanthodian dermal elements - fin spines and dentigerous jaw bones - were illustrated as outline drawings by Mark-Kurik \& Novitskaya (1977, figs. 7-9); they considered the specimens to possibly be from new genera, but noted the similarity of the noded-ridged spines with those of climatiid acanthodians from the Welsh Borderland. We recognise this form (Mark-Kurik \& Novitskaya 1977, fig. 7) as most similar to spines of Nostolepis spp. from the late Silurian-Lochkovian of the Baltic (Gross 1971, pl. 8) and the Welsh Borderland (Newman et al. 2017, fig. 8F). The fin spines with four flat smooth ridges on each side (Mark-Kurik \& Novitskaya 1977, fig. 8) resemble those assigned by Gross (1971, pl. 9.1,2) to the ischnacanthid Gomphonchus?, and also those of Ischnacanthus spp. from the Lochkovian of Scotland (Watson 1937, fig. 10) and the Welsh Borderland (White 1961, pl. 45.4). The jaw bone fragment (Mark-Kurik \& Novitskaya 1977, fig. 9) is comparable with those of acritolepid and poracanthodid ischnacanthiforms (e.g., Valiukevičius 1992, 2003a) from the Lochkovian of Severnaya Zemlya. Thelodonts have also been described from Novaya Zemlya, including Thelodus sculptilis and T. sp. from the late Silurian; Turinia pagei, T. polita and Nikolivia sp. from the Lochkovian Kamenka Bay Regional Stage, and Amaltheolepis winsnesi from the Emsian Sinelnikov Regional Stage (Karatajute-Talimaa 2000; Cherkesova et al. 2000). The heterostracan Tolypelepis sp. was found in the upper Silurian Konstantin Formation of North Island (Shkarubo 2013).

Early Devonian acanthodians have been described from several Arctic regions that were relatively close by at the time, including: Severnaya Zemlya: acanthodian articulated fish and isolated scales described by Valiukevičius (1992, 1994, 2003a); Spitsbergen: acanthodian scales, jaw bones and fin spines reported by Ørvig $(1957,1969)$, Blieck et al. (1987), Ilyes (1995) and Harland (1997), plus Pragian-Emsian acanthodian trace fossils Undichna by Wisshak et al. (2004); and Chukotka: rare acanthodian scales described by Mark-Kurik et al. (2013). The late Silurian-Early Devonian acanthodians from the Baltic countries, on the other hand, have been extensively described, starting with Pander (1856).

A new vertebrate assemblage including the acanthodian scales described below was found during the expedition of Karpinskiy Russian Geological Research Institute (St. Petersburg, VSEGEI), supported by Ministry of Mineral Resources of Russia, in 2015 in the region of Inostantsev Bay, North Island of Novaya Zemlya Archipelago. 


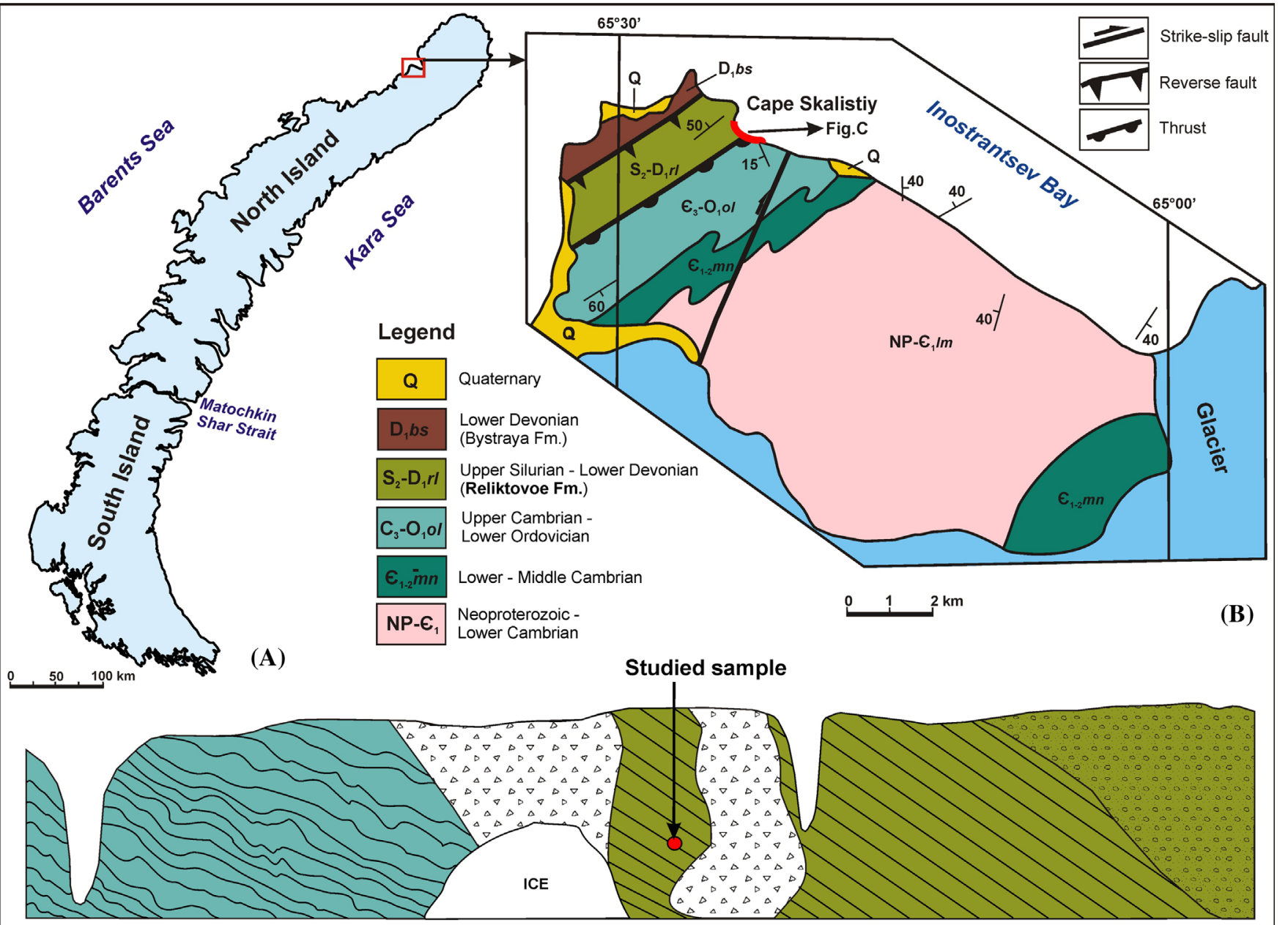

$100 \mathrm{~m}$

(C)

Upper Cambrian - Lower Ordovician shales (Oleniy Fm.)

Upper Silurian-Lower Devonian shales (Reliktovoe Fm.)

Upper Silurian-Lower Devonian conglomerates (Reliktovoe Fm.)

$\triangle \Delta_{\Delta} \Delta_{\Delta}$ Talus

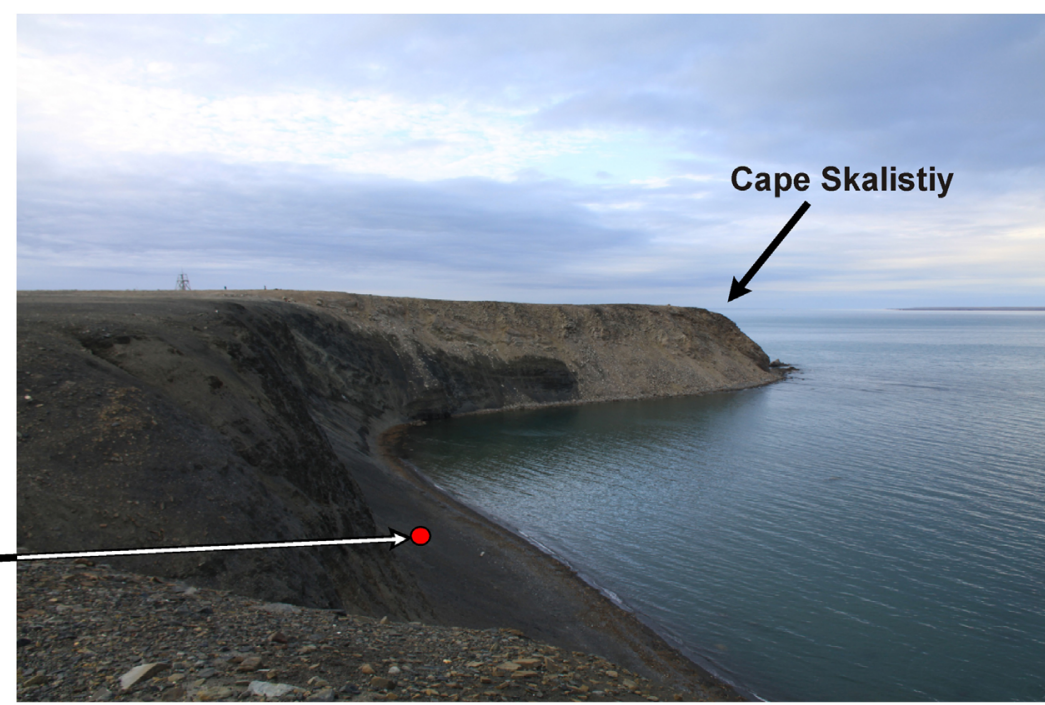

Figure 1. A, B. Maps showing the location of the studied section on North Island, Novaya Zemlya. C. Geological section of coast outcrop at Cape Skalistiy. D. Photograph of studied outcrop with position of fish sample.

\section{Geological setting}

Novaya Zemlya Archipelago is the largest archipelago of the Russian Arctic, located in the Arctic Ocean surrounded by the Barents and Kara seas. It consists of two large islands, South and North, separated by Matochkin Shar strait. Novaya Zemlya is structurally part of the Uralian Orogen Belt. The archipelago represents the exposed crustal fragment formed as a result of Early Mesozoic orogeny. Novaya Zemlya was the northern part of Baltica in the Silurian and Early Devonian.

The studied area is situated in the northernmost part of the archipelago, on the western coast of Inostantzev Bay, Barents Sea (Fig. 1A, B). This area comprises the variously deformed strata of the 
latest Neoproterozoic (?) to Devonian. The latest Neoproterozoic (?) - Middle Cambrian deposits are intensively deformed alternating argillites, siltstones with subordinate beds of sandstones and limestones (in the upper part of the succession). The intensively deformed Upper Cambrian - Lower Ordovician strata comprise black shales with rare beds of limestones. The upper Silurian Lower Devonian Reliktovoe Formation is represented by weakly deformed black shales, argillites and siltstones with rare beds of clayey limestones and thick beds of conglomerates at the top of the succession. The Reliktovoe Formation was dated by a brachiopod assemblage as Pridoli - Lochkovian (Bondarev \& Andreeva 1981; Guo et al. 2010). The overlying Lower Devonian Bystraya Formation includes limestones with interlayers of dolomites, siltstones and sandstones. The formation contains corals, brachiopods and ostracods which indicate the age as the Lochkovian - Pragian (Bondarev \& Andreeva 1981; Guo et al. 2010).

The sample 5-v15-43 which yielded the studied fish microremains was collected from the thin layer of clayey limestone within black shales of the upper Silurian-Lower Devonian Reliktovoe Formation in outcrop near Cape Skalistiy (Fig. 1 C, D).

\section{Material and methods}

The studied scales of acanthodians were obtained from acidtreated samples collected for microfauna. The fish microremains were micrographed on the scanning electron microscopes Cambridge CamScan-4 and Tescan VEGA-II XMU. Thin sections of selected scales were imaged using an Olympus BX-50 transmission microscope and DP-12 imaging system. The specimens are housed in the Paleontological Museum of St. Petersburg State University, St. Petersburg, Russia (PM SPU 92).

\section{Systematic palaeontology}

Class Acanthodil Owen, 1846

Order IsCHNACANTHIFORMES BERG, 1940

FAMILY IsCHNACANTHIDAE WOODWARD, 1891

Genus Gomphonchus (PANDER, 1856)

Type species: - Gomphodus sandelensis (Pander, 1856)

Gomphonchus mediocostatus Vergoossen, 1999a

(Fig. 2)

Material. - At least 28 scales including PM SPU 92-1 - 92-12 and two scale thin sections; western coast of Inostantzev Bay, North Island, Novaya Zemlya; sample 5-v15-43, Reliktovoe Formation, upper Silurian-Lower Devonian.

Description. - The scales are from $0.3 \mathrm{~mm}$ (Fig. 2A, B) to $0.9 \mathrm{~mm}$ (Fig. 2C) long and wide, with most being slightly wider than long, and up to $0.7 \mathrm{~mm}$ high. The crown surface is flat and horizontal, and in nearly all scales the anterior margin is curved and sharply demarcated. The crown is ornamented with two (Fig. $2 \mathrm{~A}$ ) to seven (Fig. 2C, D) subparallel ridges running from the anterior edge into the posterior half of the crown, often to the posterolateral edges. On some scales the ridges tend to converge towards the posterior corner (Fig. 2B), rather than being subparallel. The ridges are sharp-crested, in rare instances they bifurcate anteriorly (Fig. 2E, F). The two median ridges are more widely separated than the other ridges on some scales (Fig. 2F, G), but mostly the ridges are more or less equally spaced. Some scales have one or two oblique ridges lateral to the main subparallel ridges, running from the anterior edge towards the more medial ridges (Fig. 2E, H). Most scales have straight posterolateral edges converging at about $80^{\circ}$, but some scales have "staggered" posterolateral edges (Fig. 2C, F). The crown growth layers are sometimes visible in the posterior half of the crown, particularly on scales with shorter ridges, possibly caused by abrasion; about four growth zones are discernible (Fig. 2I). The scale neck is deep and concave all round, with vertical ridges ("buttresses") posteriorly between canal openings (Fig. 2J). A sharp rim separates the neck from the base, which is moderately convex with its greatest depth forward of centre (Fig. 2E). The base is slightly wider than the crown. One scale has a straight anterior crown margin that parallels the anterior edge of the base (Fig. 2K).

A detached scale crown (Fig. 2L) and another whole scale were sacrificed for thin sectioning (Fig. 2M, N). Histological structure of the scale crowns corresponds to the Gomphonchus type, as described by Gross (1971), with dense orthodentine-like tubules filling the crown growth zones (Fig. 2M). Scale bases have mostly been recrystallised (Fig. $2 \mathrm{~N}$ ), obscuring the original structure.

Comparison. - Valiukevičius (2003b) described the histological structure of G. mediocostatus scales as having bushy and uniform ascending vascular canals in the crown, frequently without main branches, numerous thin growth lamellae and completely acellular bone in the bases. The features preserved in the Novaya Zemlya scales (i.e., the dentine) appear comparable to those listed by Valiukevičius (2003b) as distinguishing this species from the closely related G. minicostatus Valiukevičius, 2003.

Occurrence. - Erratic limestones (upper Pridoli) from the northern Netherlands (Vergoossen 1999a); ? Man Brook 7 locality (uppermost Pridoli), Welsh Borderland, UK (Vergoossen 1999a, 1999b, 2000); Jūra, Rietavas and Lapès formations (upper Pridoli) and Tilžè Formation (Lochkovian), Lithuania (Valiukevičius 2003b, 2005); Greben' Regional Stage (Pridoli), Timan - Pechora Province, Russia (Valiukevičius 2003b); Reliktovoe Formation (Pridoli- Lochkovian), Inostantzev Bay, Novaya Zemlya.

Family Poracanthodidae Vergoossen, 1997

Genus Gomphonchoporus Vergoossen, 1999a

Gomphonchoporus hoppei (Gross, 1971)

(Fig. 3A-C)

Material. - Four scales including PM SPU 92-13 - 92-15; western coast of Inostantzev Bay, North Island, Novaya Zemlya; sample 5-v15-43, Reliktovoe Formation, upper Silurian-Lower Devonian.

Description. - The scales are 0.7-1.0 mm wide. Scale crowns are poorly preserved (especially Fig. 3A), but appear relatively flat, with up to ten short radial ridges (Fig. 3B) along the rounded anterior margin. When preserved, the posterior crown extends behind the posterior corner of the base (Fig. 3C). Scale bases are broader than long, and broader than the crown; the base is as deep as the crown plus neck, and is somewhat lemon-shaped in dorsal or ventral view.

Comparison. - Valiukevičius (1998) listed occurrences of Gomphonchus hoppei and Gomphonchus aff. hoppei in the Prídolí-Lochkovian of the Baltic; he distinguished the latter from the former by the "lack of lowered distal area on the crown with pore canal openings" (Valiukevičius 1998, p. 41). The few specimens we have from Novaya Zemlya correspond to 

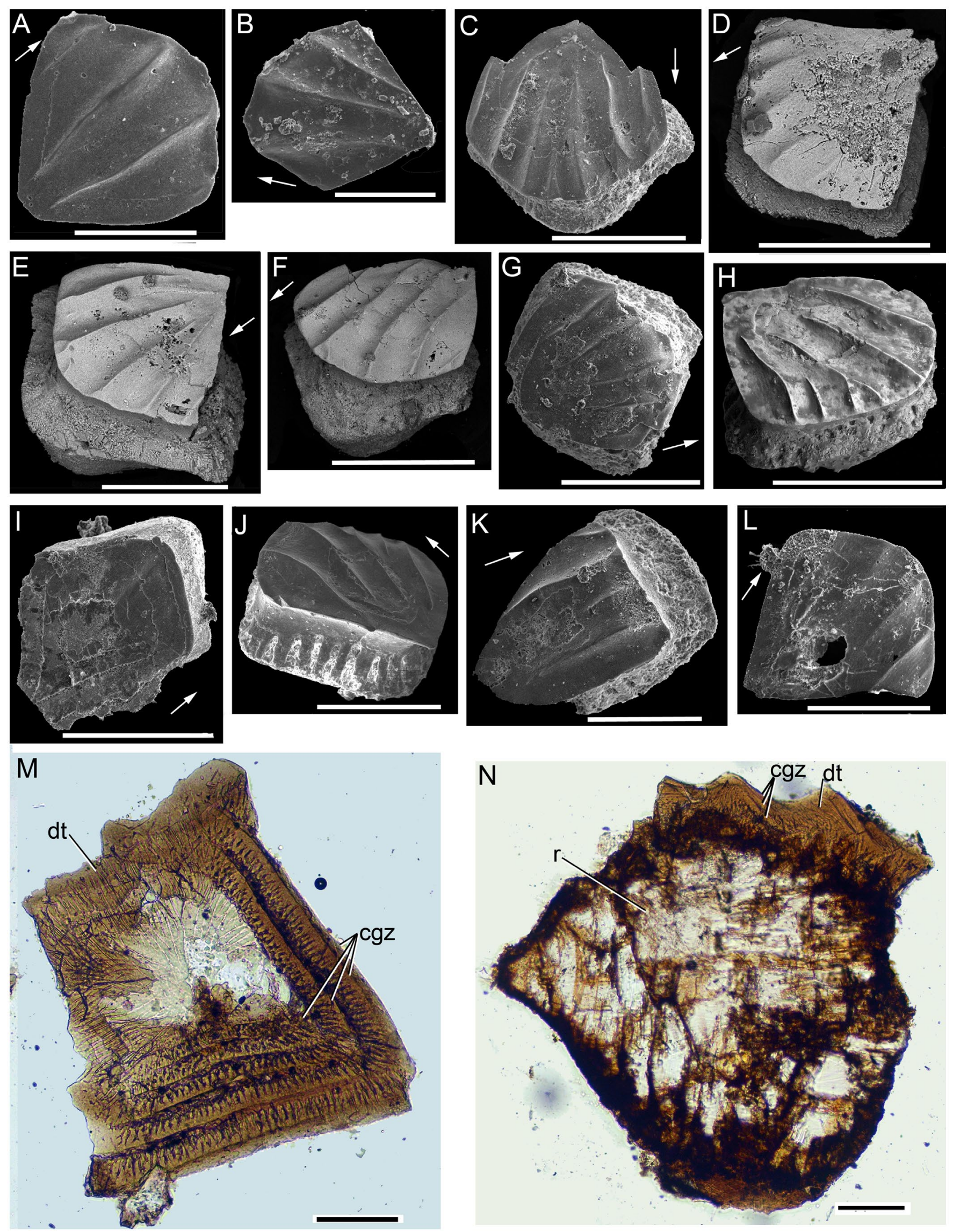

Figure 2. Gomphonchus mediocostatus Vergoossen, 1999 scales, Reliktovoe Formation of Novaya Zemlya. A. PM SPU 92-1, crown view; B. PM SPU 92-2, detached crown, crown view; C. PM SPU 92-3, crown view; D. PM SPU 92-4, crown view; E. PM SPU 92-5, laterocrown view; F. PM SPU 92-6, anterocrown view; G. PM SPU 92-7, crown view; H. PM SPU 92-8, laterocrown view; I. PM SPU 92-9, crown view; J. PM SPU 92-10, posterocrown view; K. PM SPU 92-11, crown view; L. PM SPU 92-12, crown view; M. NZ_1, horizontal section of crown; $\mathbf{N}$. NZ_2, oblique vertical section.

Notes: A-L are SEM images. Abbreviations: cgz, crown growth zones; dt, dentine tubules; r, remineralisation. Scale bars $=0.1 \mathrm{~mm}$ in M, N; $0.2 \mathrm{~mm}$ in A, B; $0.3 \mathrm{~mm}$ in E,K,L; $0.5 \mathrm{~mm}$ in C,D,F,G,H,I,J. 

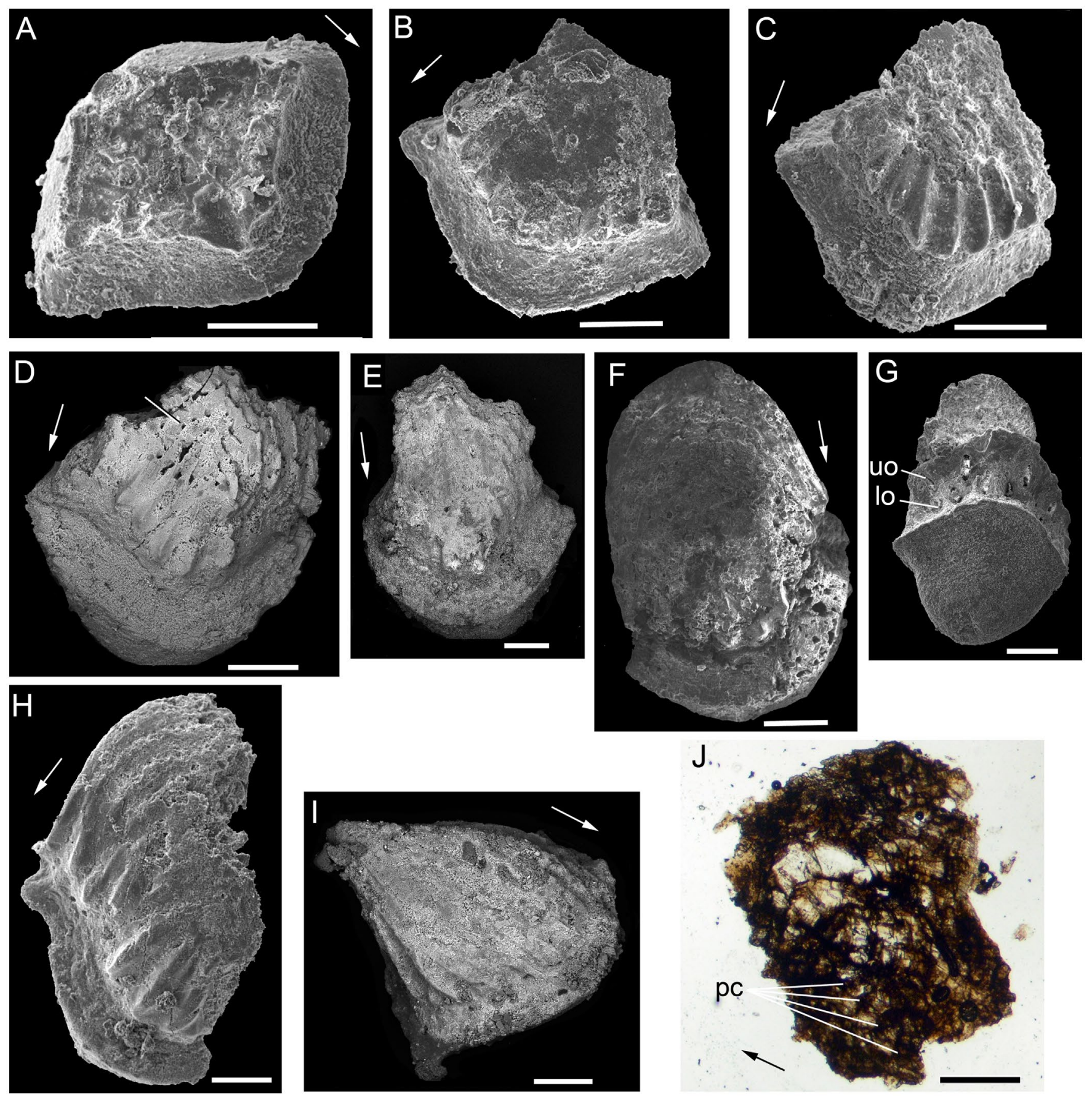

Figure 3. Poracanthodid acanthodian scales from the Reliktovoe Formation of Novaya Zemlya. A-C, Gomphonchoporus hoppei (Gross, 1971). A. PM SPU 92-13, crown view; B. PM SPU 92-14, crown view; C. PM SPU 92-15, crown view. D-J. Taimyrolepis composita Valiukevičius, 1994. D. PM SPU 92-16, crown view; E. PM SPU 92-17, crown view; F. PM SPU 92-18, crown view; G. PM SPU 92-19, posterobasal view; H. PM SPU 92-20, crown view; I. PM SPU 92-21, laterocrown view; J. NZ_3, horizontal section of crown.

Notes: A-I are SEM images; arrows indicate anterior direction. Abbreviations: lo, lower neck canal opening; pc, row of crosscut pore canals; uo, upper neck canal opening. Scale bars $=0.2 \mathrm{~mm}$.

the latter group. Vergoossen (1999a) regarded both scale forms as variants of Gomphonchoporus hoppei, based on the occurrence of well-preserved specimens of all morphovariants in an erratic boulder, and the gradation between the forms. Following Vergoossen (1999a), the Novaya Zemlya scales correspond to Gross' (1971) morphological form type (1). Vergoossen (1999a) erected the new genus Gomphonchoporus; the presence of a pore canal system in some of the scale variants indicated the taxon should be assigned to the Poracanthodidae rather than the Ischnacanthidae, as the latter do not have pore canals. This necessitated the erection of a new genus, because Gomphonchus spp. lack a pore canal system. Subsequently Valiukevičius (2005) tabled occurrences of Gomphonchus hoppei and Gomphonchus sp. cf. G. hoppei in the Jüra Formation, Lithuania, but did not specify how he distinguished between the two. It seems possible that the latter taxon is the descriptor for the same scales which he variously labelled Gomphonchus aff. hoppei or Gomphonchus cf. hoppei in earlier papers (e.g., Valiukevičius 1998, 2000, 2004). 
We follow Vergoossen (1999a), and assign all these variants to the same taxon, Gomphonchoporus hoppei.

Occurrence. - Erratic limestones (upper Pridoli) from the northern plains of Germany and the Netherlands (Gross 1971; Vergoossen 1999a); Pridoli, Poland and Central Urals (Märss 1997); Man Brook 7 locality (uppermost Pridoli), Welsh Borderland, UK (Vergoossen 1999a, 2000); Jūra, Rietavas and Lapès formations (upper Pridoli) and Tilžè Formation (Lochkovian), Lithuania (Valiukevičius 2003b, 2005); and Borschevo Regional Stage (Lochkovian), Belarus (Plax 2011, 2015); Greben' Regional Stage (Pridoli), Timan - Pechora Province, Russia (Valiukevičius 2003b); Reliktovoe Formation (Pridoli- Lochkovian), Inostantzev Bay, Novaya Zemlya.

Genus Taimyrolepis Valiukevičius, 1994

Diagnosis (based on Valiukevičius translation in 1995, pers. comm.). - Large scales $(0.7--1.25 \mathrm{~mm})$ with compound ridged crown. Five to seven rough, smooth, parallel or fan-like ridges prolonged through the whole crown. Three to four medial ridges may grow together and make a higher area. At the distal edge they are lower, cut by cross grooves with openings of pore canals. Histological structure of "Nostolepis" type. Oriented mesodentine is lacking. The simple mesodentine of the crown (3-4 growth lamellae) is pierced by narrow dentine canals with lacunae. Wide main branches of canals are not seen. The thin-layered bone of the base contains rare osteocyte cavities.

\section{Taimyrolepis composita Valiukevičius, 1994}

\section{(Fig. 3D-J)}

Material. - Eight scales including PM SPU 92-16 - 92-21 and one scale thin section; western coast of Inostantzev Bay, North Island, Novaya Zemlya; sample 5-v15-43, Reliktovoe Formation, upper Silurian-Lower Devonian.

Description. - The scales are 0.8 to $1.2 \mathrm{~mm}$ wide. The anterior margin of the crown is strongly curved in outline, and rises up directly from the neck/base (Fig. 3D-F). Up to ten ridges radiate back from the anterior edge. Serrated-edged plates overlap to form the crown posterior to the ridges (Fig. 3D,E). Pore openings are rarely visible between the plates; possibly these are only exposed through erosion of the crown, which is poorly preserved. The neck is relatively deep posteriorly, and penetrated by canal openings under the posterior crown overhang and across the middle of the neck (Fig. 3G). The sharp neck-base rim is oval to lemon shaped in outline, and the base is deep. A few scales differ from this general form: one is wide with a sinuous anterior margin (Fig. 3H), and another is more dorso-ventrally flattened (Fig. 3I) than the normal presumed flank scales.

Histology. Unfortunately, the whole of the scale sacrificed for sectioning (Fig. 3J) was remineralised, obscuring the internal structure. Parallel unbranching dentine tubules extend through the crown growth zones posteriorly, and radial lines of pore canals are also present in the posterior crown. The poor preservation of the crowns as well as the bases indicates that the upper levels of the crown tissue is less highly mineralised than in scales of G. mediocostatus.

Comparison. - Valiukevičius (1988) originally assigned this scale form to Machaeracanthus?, but scales of Machaeracanthus lack a pore canal system (Gross 1973; Burrow et al. 2013). Burrow et al. (2013) erected a new genus Machaeraporus for scales from the Pridoli of Nova Scotia, Canada originally assigned to Cheiracanthoides stonehousensis Legault, 1968, which have a pore canal system, but in Machaeraporus the canals only open out on the underside of the posterior crown, not the surface. Crown morphology of the Novaya Zemlya scales is similar to that of Radioporacanthodes liujingensis (Wang, 1992) from the Pragian - early Emsian of Guangxi county, China, but the latter differ in having sharp-crested crown ridges and a very high neck anteriorly (Wang 1992, pl. 3 fig. 1b; Burrow et al. 2000, pl. 2 fig. 7), pore canal openings only in the posterior third of the crown, and in lacking overlapping layers forming the posterior crown (as far as can be estimated by the few known well-preserved scales of $R$. liujingensis). Because the crown ornament and histological structure are poorly preserved in the Novaya Zemlya scales, a close comparison with scales from other taxa is limited to their general shape and morphology, and these fall within the range shown by the type material of T. composita. Valiukevičius (1994) compared the structure of the posterior crown with that in Gomphonchus hoppei (as noted above, this species is now referred to Gomphonchoporus hop$p e i)$, but noted that the latter species only has radial ridges, without diverging ridges on the lateral areas of the crown (Fig. 3D, I). Wellpreserved scales in a late Pridoli East Baltic - derived erratic limestone from the northern Netherlands, one of which Vergoossen (1999a, figs. 42-44) nominated as neotype for Gomphonchoporus hoppei, show a similar structure in the posterior crown to that in some of the Novaya Zemlya scales, with overlapping growth zones. The G. hoppei scales differ in having straight posterolateral edges on most of the growth zones, with serrated/zigzag edges only on the youngest zone, if present at all. On T. composita scales, all the posterior growth zones have serrated/zigzag edges. The two species also differ in the extent of the scale pore canal system, which is only present in one of the G. hoppei morphotypes, where it is limited to the posterolateral areas of the crown. In T. composita type material, the pore canal system comprises large branching sinuous canals that penetrate the scale base as well as the crown (Valiukevičius 1994, fig. 72.4); we cannot determine the presence or absence of this feature in the Novaya Zemlya scales, but consider their morphology is distinctive enough to assign to this species.

Remarks. - Valiukevičius (1988) originally considered this species to possibly belong to Machaeracanthus, before erecting a new genus and species Taimyrolepis composita Valiukevičius, 1994, assigned to the Order Climatiiformes, Family Climatiidae. This order is no longer considered valid (e.g., Burrow 2002), and Taimyrolepis does not show any diagnostic characters to support assigning it to the Climatiidae. Indeed, the pore canal system identified within the crown and base of T. composita scales indicate the species should rather be assigned to the poracanthodid ischnacanthiforms.

Occurrence. - Uryum Beds, Ust' Tareya Regional Stage (Lochkovian), Tareya River, Taimyr Pennynsula, Russia (Valiukevičius 1994); Reliktovoe Formation (PridoliLochkovian), Inostantzev Bay, Novaya Zemlya.

\section{Discussion}

Although the acanthodian scale assemblage from Reliktovoe Formation of western coast of Inostantzev Bay, North Island, Novaya Zemlya is limited in abundance and diversity, the taxa present indicate a latest Pridoli - earliest Lochkovian age based 
on their stratigraphic distribution elsewhere. Gomphonchoporus hoppei s.s. is recorded throughout the Baltic countries (Valiukevičius 2000), Belarus (Plax 2015), Poland, Central Urals, Russia (Märss 1997) and probably Severnaya Zemlya Archipelago (Valiukevičius 2003a); plus the Welsh Borderland, UK (Vergoossen 1999a), first appearing in the lower Pridoli (Jura Regional Stage) in Lithuania (Valiukevičius 2005, fig. 7) and ranging up to the middle Lochkovian (Valiukevičius 2000, fig. 1). Gomphonchus mediocostatus is recorded from the Baltic countries and the Welsh Borderland, but is only recorded from the uppermost Pridoli to Lochkovian (Vergoossen 1999a; Valiukevičius 2005, fig. 7). Taimyrolepis composita is known from the Lochkovian of Tareya River, Taimyr Pennynsula. The acanthodian macroremains described by Mark-Kurik \& Novitskaya (1977) are not very helpful in assessing the palaeogeography at a slightly younger time (upper Lochkovian), because we only recognise the taxa in their descriptions at a suprageneric level, or from a widespread genus (Nostolepis).

The acanthodian fauna from the Pridoli - Lochkovian of Novaya Zemlya includes two taxa Gomphonchus mediocostatus and Gomphonchoporus hoppei widely distributed in the southern Baltica palaeogeographic province and one species Taimyrolepis composita which occurred in the Siberian province. During the late Silurian - early Devonian, Novaya Zemlya and the Ural Mountains formed the northern margin of Baltica (Cocks \& Torsvik 2005), with a relatively wide ocean separating the land areas of Baltica and the Siberian terrane (Cocks \& Torsvik 2016, fig. 8.1a). The invertebrate faunas from the Pridoli - Lochkovian of Novaya Zemlya are close in taxonomic composition to those from the Urals and the Timan-Pechora Province as well as from Severnaya Zemlya (e.g., Modzalevskaya 1985; Nekhorosheva \& Patrunov 1999; Abushik \& Evdokimova 1999), and heterostracan agnathan faunas from Spitsbergen, Novaya Zemlya and Severnaya Zemlya show close similarities during the Early Devonian (Pernègre \& Blieck 2016). Unfortunately, although acanthodians have been recorded as commonly occurring in the Lochkovian Red Bay Group in west Spitsbergen (Ørvig 1969; Blieck et al. 1987), the material has not been systematically described or figured, being mostly nominally assigned to the genera "Nostolepis", "Gomphonchus", and "Onchus". A poorly preserved and sparse acanthodian fauna is known from Chukotka (Mark-Kurik et al. 2013), but none of the species recorded there are represented in the Novaya Zemlya fauna.

Whereas the distribution of most faunas was restricted to the continental shelf areas of the different terranes, acanthodians were nektonic and able to migrate across deeper waters. The distribution of Taimyrolepis composita indicates the northern Baltica and Siberia terrane faunas at that time could have been connected via Severnaya Zemlya and Taimyr.

\section{Acknowledgements}

The authors are most grateful to Dr Tatyana Tolmacheva (Karpinskiy Russian Geological Research Institute, St. Petersburg) for extraction of fish remains. Scientific researches by AOI and VBE were performed at the Center for Geo-Environmental Research and Modeling (GEOMODEL) of Research park of St. Petersburg State University. The work was performed according to the Russian Government Program of Competitive Growth of Kazan Federal University. CJB acknowledges the support of the Queensland Museum.

\section{Disclosure statement}

No potential conflict of interest was reported by the authors.

\section{Funding}

VBE was supported by Russian Foundation for Basic Research (RFBR) [grant number 16-55-20012].

\section{ORCID}

Carole J. Burrow (D) http://orcid.org/0000-0002-1458-070X

Alexander O. Ivanov (iD http://orcid.org/0000-0002-0790-2344

\section{References}

Abushik, A.F. \& Evdokimova, I.O., 1999: Lagoonal to normal marine Late Silurian - Early Devonian ostracode assemblages of the Eurasian Arctic. Acta Geologica Polonica 49(2), 133-143.

Berg, L.S., 1940: Sistema ryboobraznykh i ryb, nyne zhivushchikh i ickopaemykh [System of recent and fossil agnathans and fishes]. Trudy Zoologicheckogo Instituta Akademii Nauk SSSR [Transactions of the Zoological Institute of USSR Academy of Sciences] 5, 85-517 [in Russian].

Blieck, A., Goujet, D. \& Janvier, P., 1987: The vertebrate stratigraphy of the Lower Devonian (Red Bay Group and Wood Bay Formation) of Spitsbergen. Modern Geology 11, 197-217.

Bondarev, V.I. \& Andreeva, I.A., 1981: Nizhnedevonskie otlozheniya Severnogo ostrova Novoi Zemli [Lower Devonian deposits of the North Island in Novaya Zemlya]. In V.I. Bondarev (ed.): Paleontologicheskaya osnova stratigraficheskih shem paleozoya i mezozoya ostrovov Sovetskoi Arktiki, 5-13. NIIGA, Leningrad [in Russian].

Burrow, C.J., 2002: Lower Devonian acanthodian faunas and biostratigraphy of south-eastern Australia. Memoirs of the Association of Australasian Palaeontologists 27, 75-137.

Burrow, C.J., Turner, S., Nowlan, G.S. \& Denison, R.H., 2013: Vertebrate microremains from the late Silurian of Arisaig, Nova Scotia, Canada. Journal of Paleontology 87, 1041-1059. doi:https://doi.org/10.1666/ 12-154.

Burrow, C.J., Turner, S. \& Wang, S.-T., 2000: Devonian microvertebrates from Longmenshan, Sichuan, China: Taxonomic assessment. Courier Forschungsinstitut Senckenberg 223, 391-452.

Cherkesova, S.V., Sobolev, N.N. \& Spassky, Ya.N., 2000: Devonian stage boundaries in Novaya Zemlya. Courier Forschungsinstitut Senckenberg $225,319-322$

Cocks, L.R.M. \& Torsvik, T.H., 2005: Baltica from the late Precambrian to mid-Palaeozoic times: the gain and loss of a terrane's identity. Earth-Science Reviews 72, 39-66. doi:https://doi.org/10.1016/j. earscirev.2005.04.001.

Cocks, L.R.M. \& Torsvik, T.H., 2016: Earth history and palaeogeography. Devonian, 124-137. Cambridge University Press, Cambridge.

Gross, W., 1971: Downtonische und Dittonische Acanthodier-Reste des Ostseegebietes. Palaeontographica Abt A 136, 1-82.

Gross, W., 1973: Kleinschuppen, Flossenstacheln und Zähne von Fischen aus europäischen und nordamerikanischen Bonebeds des Devons. Palaeontographica Abt A 142, 51-155.

Guo, L., Schekoldin, R. \& Scott, R., 2010: The Devonian succession in northern Novaya Zemlya, Arctic Russia: sedimentology, palaeogeography and hydrocarbon occurrence. Journal of Petroleum Geology 33, 105-121.

Harland, W.B., 1997: The geology of Svalbard. Chapter 16. Devonian history. Geological Society, London, Memoirs 17, 289-309. doi: https://doi.org/10.1144/gsl.mem.1997.017.01.16.

Ilyes, R.R., 1995: Acanthodian scales and worm tubes from the Kapp Kjeldsen Division of the Lower Devonian Wood Bay Formation, Spitsbergen. Polar Research 14, 89-92.

Karatajute-Talimaa, V.N., 2000: Significance of thelodonts (Agnatha) in correlation of the uppermost Ordovician to Lower Devonian of the northern part of Eurasia. Courier Forschungsinstitut Senckenberg 223, $69-80$. 
Legault, J.A., 1968: Conodonts and fish remains from the Stonehouse Formation, Arisaig, Nova Scotia. Canada Geological Survey Bulletin $165,3-48$.

Mark-Kurik, E. \& Novitskaya, L., 1977: Rannedevonskaya ikhtiofauna na Novoy Zemle [The Early Devonian fish fauna on Novaya Zemlya]. Proceedings of the Academy of Sciences of the Estonian SSR, Chemistry and Geology 26, 143-149 [in Russian, with English abstract].

Märss, T., 1997: Vertebrates of the Přídolí and Silurian-Devonian boundary beds in Europe. Modern Geology 21, 17-41.

Mark-Kurik, E., Blieck, A., Burrow, C.J. \& Turner, S., 2013: Early Devonian fishes from coastal De Long Strait, central Chukotka, Arctic Russia. Geodiversitas 35, 545-578.

Modzalevskaya, T.L., 1985: Brachiopods from the Silurian and Early Devonian of the European Part of the U.S.S.R. Nauka, Moscow. 128 pp. [in Russian].

Nakrem, H.A., 2007: The 1921 O. Holtedahl Novaya Zemlya collection geology (illustrated atlas). Part I: Introduction. Natural History Museum, University of Oslo, Oslo. 26 pp.

Nekhorosheva, L.V. \& Patrunov, D.K., 1999: The chief WenlockianLochkovian benthic communities of the Vaigach to southern Novaya Zemlya region. In A.J. Boucot \& J.D. Lawson (eds.): Paleocommunities a case study from the Silurian and Lower Devonian, 488-495. Cambridge University Press, Cambridge.

Newman, M.J., Burrow, C.J., Davidson, R.G., den Blaauwen, J.L. \& Jones, R., 2017: Comparison of the vertebrate faunas of the Lower Old Red Sandstone of the Anglo-Welsh Basin with contemporary faunas in Scotland. Proceedings of the Geologists' Association 128, 447-459. doi: https://doi.org/10.1016/j.pgeola.2016.12.007.

Obruchev, D.V., 1973: Znacheniye pozvonochnykh dlya korrelyatsii siluriyskikh i nizhne-srednedevonskikh otlozheniy SSSR [Importance of vertebrates for correlation of the Silurian and Lower-Middle Devonian deposits of USSR]. In Trudy III Mezhdunarodnogo simpoziuma po granitse silura i devona i stratigrafi nizhnego i srednego devona [Stratigraphy of the Lower and Middle Devonian. Transactions of the III International Symposium on the Silurian-Devonian Boundary and Stratigraphy of the Lower and Middle Devonian], Vol. II, Nauka, Leningrad, 189-197 [in Russian].

Ørvig, T., 1957: Notes on some Paleozoic lower vertebrates from Spitsbergen and North America. Saertrykk av Norsk geologisk tidsskrift 37, 285-353.

Ørvig, T., 1969: The vertebrate fauna of the Primaeva Beds of the Frænkelryggen Formation of Vestspitsbergen and its biostratigraphic significance. Lethaia 2(3), 219-239.

Owen, R., 1846: Lectures on the comparative anatomy and physiology of the vertebrate animals delivered at the Royal College of Surgeons, England in 1844 and 1846. Part I, Fishes, i-xi+1-304. Longman, Brown, Green and Longmans, London.

Pander, C.H., 1856: Monographie der fossilen Fische des silurischen Systems der Russisch-Baltischen Gouvernements. Obersilurische Fische. Buchdruckerei der Kaiserlichen Akademie der Wissenschaften, St. Petersburg. 91 pp.

Pernègre, V.N. \& Blieck, A., 2016: A revised heterostracan-based ichthyostratigraphy of the Wood Bay Formation (Lower Devonian, Spitsbergen), and correlation with Russian Arctic archipelagos. Geodiversitas 38, 5-20. doi:https://doi.org/10.5252/g2016n1a1.

Plax, D.P., 2011: Devonian ichthyofauna of the Volyn Monocline. Lithosphera 35(2), 12-21.

Plax, D.P., 2015: Ichthyofauna from the Lower Devonian (Lochkovian) deposits of the southwestern part of Belarus. Lithosphera 2(43), 19-36.
Shkarubo, S.I., (ed.), 2013: Obyasnitelnaya zapiska $k$ Gosudarstvennoy geologicheskoy karte Rossiyskoy Federatsii, List T-41-44 - Mys Zhelaniya [Explanatory Notes to the State Geological Map of Russian Federation, Sheet T-41-44-Zhelaniya Cap], St. Petersburg. 200 pp. [in Russian].

Valiukevičius, J., 1988: Correlation of Lower and Middle Devonian deposits of the USSR with acanthodian assemblages. Canadian Society of Petroleum Geologists Memoirs 14(3), 601-607.

Valiukevičius, J.J., 1992: First articulated Poracanthodes from the Lower Devonian of Severnaya Zemlya. In E. Mark-Kurik (ed.): Fossil Fishes as Living Animals, 193-214. Academy of Sciences of Estonia, Tallinn.

Valiukevičius, J.J., 1994: Acanthodians and their stratigraphic significance. In S. Cherkesova, V. Karatajute-Talimaa \& R. Matukhin (eds.) Stratigraphy and Fauna of the Lower Devonian of the Tareya Key Section (Taimyr), 131-197, 236-243. Leningrad, Nedra [in Russian].

Valiukevičius, J.J., 1998: Acanthodians and zonal stratigraphy of Lower and Middle Devonian in East Baltic and Byelorussia. Palaeontographica Abt A 248, 1-53.

Valiukevičius, J.J., 2000: Acanthodian biostratigraphy and interrregional correlations of the Devonian of the Baltic States, Belarus, Ukraine and Russia. Courier Forschungsinstitut Senckenberg 223, 271-289.

Valiukevičius, J.J., 2003a: Devonian acanthodians from Severnaya Zemlya Archipelago (Russia). Geodiversitas 25, 131-204.

Valiukevičius, J.J., 2003b: New Late Silurian to Middle Devonian acanthodians of the Timan-Pechora region. Acta Geologica Polonica 53, 209-245.

Valiukevičius, J., 2004: Silurian succession of the Luzni-4 borehole (Latvia). Acta Universitatis Latviensis 679, 120-147.

Valiukevičius, J., 2005: Silurian acanthodian biostratigraphy of Lithuania. Geodiversitas 27, 349-380.

Vergoossen, J.M.J., 1997: Revision of poracanthodid acanthodians. In A. Ivanov, M.V.H. Wilson \& A. Zhuravlev (eds.): Circum-Arctic Palaeozoic vertebrates: biological and geological significance, Ichthyolith Issues S.P. $3,44-46$.

Vergoossen, J.M.J., 1999a: Late Silurian fish microfossils from an East Baltic-derived erratic from Oosterhaule, with a description of new acanthodian taxa. Geologie en Mijnbouw 78, 231-251.

Vergoossen, J.M.J., 1999b: Siluro-Devonian microfossils of Acanthodii and Chondrichthyes (Pisces) from the Welsh borderland/South Wales. Modern Geology 24, 23-90.

Vergoossen, J.M.J., 2000: Acanthodian and chondrichthyan microremains in the Siluro-Devonian of the Welsh Borderland, Great Britain, and their biostratigraphical potential. Courier Forschungsinstitut Senckenberg 223, 175-199.

Wang, N.-Z., 1992: Microremains of agnathans and fishes from Lower Devonian of Central Guangxi with correlation of Lower Devonian between Central Guangxi and Eastern Yunnan, South China. Acta Palaeontologica Sinica 31, 298-307.

Watson, D.M.S., 1937: The acanthodian fishes. Philosophical Transactions of the Royal Society (B) 228, 49-146.

White, E.I., 1961: The Old Red Sandstone of Brown Clee Hill and the adjacent area, II. Palaeontology. Bulletin of the British Museum (Natural History), Geology 5(7), 243-310.

Wisshak, M., Volohonsky, E. \& Blomeier, D., 2004: Acanthodian fish trace fossils from the Early Devonian of Spitsbergen. Acta Palaeontologica Polonica 49, 629-634.

Woodward, A.S., 1891: Catalogue of the fossil fishes in the British Museum (Natural History). Part II. British Museum (Natural History), London. $567 \mathrm{pp}$. 